\title{
MARKETING \\ IN DEVELOPING COUNTRIES
}




\title{
MACMILLAN STUDIES IN MARKETING MANAGEMENT
}

\author{
General Editor: Professor Michael J. Baker
}

University of Strathclyde

This series is designed to fill the need for a compact treatment of major aspects of marketing management and practice based essentially upon European institutions and experience. This is not to suggest that experience and practice in other advanced economies will be ignored, but rather that the treatment will reflect European custom and attitudes as opposed to American, which have tended to dominate so much of the marketing literature.

Each volume is the work of an acknowledged authority on that subject and combines distillation of the best and most up-to-date research findings with a clear statement of their relevance to improved managerial practice. A concise style is followed throughout, and extensive use is made of summaries, checklists and references to related work. Thus each work may be viewed as both an introduction to and a reference work on its particular subject. Further, while each book is self-contained, the series as a whole comprises a handbook of marketing management.

The series is designed for both students and practitioners of marketing. Lecturers will find the treatment adequate as the foundation for in-depth study of each topic by more advanced students who have already pursued an introductory and broadly based course in marketing. Similarly, managers will find each book to be both a useful aide-mémoire and a reference source.

The titles so far published in the series are:

Michael J. Baker (ed.), Marketing: Theory and Practice

Michael J. Baker and Ronald McTavish, Product Policy and Management

J. R. Bureau, Brand Management

Gordon R. Foxall, Consumer Choice

Roy W. Hill and T. J. Hillier, Organisational Buying Behaviour

Frank Jefkins, Public Relations for Marketing Management

Joanna Kinsey, Marketing in Developing Countries

James M. Livingstone, International Marketing Management

James M. Livingstone, A Management Guide to Market Research

Ronald McTavish and Angus Maitland, Industrial Marketing 


\section{MARKETING \\ IN DEVELOPING \\ COUNTRIES}

Joanna Kinsey

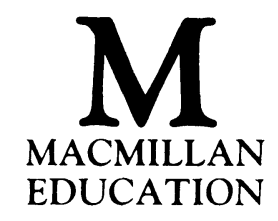


(C) Joanna Kinsey 1988

All rights reserved. No reproduction, copy or transmission of this publication may be made without written permission.

No paragraph of this publication may be reproduced, copied or transmitted save with written permission or in accordance with the provisions of the Copyright Act 1956 (as amended), or under the terms of any licence permitting limited copying issued by the Copyright Licensing Agency, 33-4 Alfred Place, London WC1E 7DP.

Any person who does any unauthorised act in relation to this publication may be liable to criminal prosecution and civil claims for damages.

First published 1988

Published by

MACMILLAN EDUCATION LTD

Houndmills, Basingstoke, Hampshire RG21 2XS

and London

Companies and representatives

throughout the world

British Library Cataloguing in Publication Data

Kinsey, Joanna

Marketing in developing countries.- (Macmillan

studies in marketing management).

1. Marketing - Developing countries

I. Title

658.8'009172' $4 \quad$ HF5415.12.044

ISBN 978-0-333-42116-1

DOI 10.1007/978-1-349-19147-5

ISBN 978-1-349-19147-5 (eBook)

Series Standing Order

If you would like to receive future titles in this series as they are published, you can make use of our standing order facility. To place a standing order please contact your bookseller or, in case of difficulty, write to us at the address below with your name and address and the name of the series. Please state with which title you wish to begin your standing order. (If you live outside the United Kingdom we may not have the rights to your area, in which case we will forward your order to the publisher concerned.)

Customer Services Department, Macmillan Distribution Ltd Houndmills, Basingstoke, Hampshire, RG21 2XS, England. 


\section{Contents}

List of Tables vi

List of Figures vii

List of Maps viii

Preface ix

Acknowledgements $\quad$ ii

\section{PART I THE ISSUES IN MARKETING IN DEVELOPING COUNTRIES}

1 The Marketing Concept and Developing Countries 3

2 The Marketing Environment in Developing Countries

3 Consumer Behaviour in Developing Countries 58

$4 \quad$ Marketing Research in Developing Countries 82

5 The Marketing Mix in Developing Countries 109

\section{PART II MARKETING IN PRACTICE IN DEVELOPING COUNTRIES}

$6 \quad$ Marketing by the State: I 143

$7 \quad$ Marketing by the State: II 177

8 Marketing by the Multinational Enterprise 210

$9 \quad$ Marketing by the Individual 258

\section{PART III ISSUES AFFECTING THE FUTURE OF MARKETING IN DEVELOPING COUNTRIES}

10 Problems and Prospects for Marketing at the Macro Level 289

11 Problems and Prospects for Marketing at the Micro Level

Appendix I The World Bank Classification of Developing and Other Countries 349

Appendix II Livingstone's Classification of Developing and Other Countries $\quad 353$

References $\quad 355$

Author Index 364

Subject Index 366 


\section{List of tables}

1.1 The characteristics of developing countries 6

1.2 The changing growth rate of GDP in selected NICs 12

1.3 Stages of economic development and marketing emphases 25

3.1 Advertising expenditures in a selection of developing countries in 1977 and $1982 \quad 75$

5.1 External factors to be considered in the formulation of the marketing mix 111

5.2 Typical modifications necessary when products designed for developed country markets are introduced to developing country markets 114

5.3 Advertising expenditure as a \% of GNP in 1982 in a selection of developing countries 120

6.1 Basic failings in agricultural planning and the relevance of marketing 163

7.1 Basic failings in industrial planning and the relevance of marketing 179

7.2 Possible roles for small firms in industrial planning 194

7.3 Barriers to the incorporation of marketing into industrial planning 198

8.1 The attractiveness of developing countries (by type) to multinational companies 217

8.2 Most likely ownership structures and market strategies according to category of host country 222

8.3 Arguments centred on the impact of the multinational 228

9.1 The impact of the Arab culture on marketing management in private enterprise 274

10.1 Exports of manufactured goods from developing countries in 1979304

11.1 Exports of electronics from South Korea 343 


\section{List of figures}

2.1 The interrelationships between the organisation and its marketing environment 34

2.2 Components of the marketing environment 35

3.1 Social class structure in the UK and the USA 63

3.2 Social class structure in many low-income countries 63

3.3 Social class structure in many large rich newly industrialised countries 63

5.1 Typical channel structure and physical distribution in developing countries 127

9.1 The marketing planning framework 281

10.1 The international product life cycle 293 


\section{List of maps}

1.1 The World Bank classification of countries 8

1.2 Livingstone's classification of countries 10 


\section{Preface}

Marketing in Developing Countries is written to complement present textbooks (notably Marketing: An Introductory Text) which are based on and written for developed countries.

The need for more marketing in developing countries is being recognised, as a means of helping minimise the effects of an increasingly competitive international climate, protectionism, plunging commodity prices, debt and numerous other difficulties which hamper economic development. For marketing offers a method of assessing whatever resources a developing country possesses and matching them with opportunities in the wider environment. It also provides the tools and techniques to ensure that modern industrial and commercial bases are built with the least disruption to local culture. Unfortunately it is usually the case that marketing is insufficiently understood or used in developing countries, while marketing training tends to be non-existent.

In order to fill this gap the Department of Marketing at Strathclyde University introduced the Master of Commerce in Marketing for Industrialising Countries degree programme in 1981. Aimed particularly at managers, government officials and academics as vocational training and applauded by Philip Kotler as an examplar for the future teaching of marketing in developing countries, it has proved extremely successful and in 1987 was made available on a Distance Learning basis. But because there was a dearth of readily-available academic textbooks covering the use of marketing in a developing country context one had to be developed.

This book is therefore aimed particularly at those who work either in the private or public sector in developing countries and who wish to develop marketing skills. Three perspectives are considered - those of the state marketer, the multinational marketer and the private sector indigenous marketer. Undoubtedly the government official plays a major role in the development of most developing countries. It is therefore essential that he or she not only understands and uses marketing him or herself but also is aware of the multinational and indigenous marketers' perspectives so that technology is acquired on the most favourable terms and the right sort of assistance is given to small firms. The private indigenous marketer 
has an increasingly important role to play as grand industrialisation schemes and highly capital-intensive projects have had to be shelved through shortage of finance or lack of success. His marketing abilities are likely to determine his chances of survival and growth, which in turn influence the state of the economy.

A second type of reader who may find the book of interest is the company executive in the developed world who is concerned with subsidiaries in and/or exporting to developing countries. It is more and more apparent that there is greater interdependence between developed and developing countries and that whereas developed world markets are reaching saturation point, the future market potential in many developing countries is enormous. The right sort of marketing skills must be developed. For this reason the book should also be used by students in the developed world for international marketing courses at both the undergraduate and postgraduate level.

No apology is made for the breadth of coverage or level of generalisation which, if taken out of context, would undoubtedly not apply to specific situations. Superficiality and over-generalisation are likely to be typical of any book which is written as a foundation for further literature of a narrower nature. However, it is hoped that the use of a classification of developing countries, based on their population and potential wealth resulting from their natural resources, and the inclusion of the three different marketing perspectives within developing countries will help to minimise the problems associated with attempting to cover all developing countries. Furthermore this allows readers to select parts of the book which are most relevant to them.

And because this book is written as part of a series and assumes that readers are familiar with Marketing: An Introductory Text other difficulties are overcome: firstly the developed world is, for the present, still the richest export market for developing countries, and in order that they may compete effectively the sophisticated marketing environment and the marketing techniques of the developed world must be understood; secondly it is a controversial point when a country moves from the 'developing' into the 'developed' category. It has already been suggested that some of the newly industrialised countries such as Singapore should be excluded from the preferential trading terms assigned to developing countries since their standard of living and other characteristics represent the developed world much more closely. But even in less fortunate developing countries the urban areas may be more akin to Western Europe or North America than to the rest of the country. In such instances marketing as practised in Western developed nations may be more appropriate and no modifications need be made. Until the range and scope of the literature increase it is again essential that the reader selects the parts of both books which are most appropriate. 
Because this book has been written primarily for the M.Com. in Marketing for Industrialising Countries degree programme, a special debt of gratitude is owed to Professor J. M. Livingstone, now Professor of Management at Glasgow University. Professor Livingstone developed and directed the M.Com. programme at Strathclyde for three years. Furthermore it is his typology of large rich, large poor, small rich and small poor developing countries which is used throughout the book.

Deepest thanks are also due to Professor M. J. Baker, Deputy Principal and Head of the Department of Marketing at Strathclyde University. As series editor he offered continual encouragement and helpful advice as well as providing a basic framework for Part I of this book, since it uses as the foundation his most widely used British marketing textbook Marketing: An Introductory Text.

Finally Mrs Jean Davidson deserves a special mention for struggling with, and attempting to make sense out of, my appalling handwriting, in the typing of the manuscript. She succeeded admirably in presenting the meaning which was intended. Undoubtedly many weaknesses and deficiencies of my own making remain and for these I accept full responsibility. But if as a result of the remaining more meaningful parts of the book marketing principles and practices are acknowledged and used to better effect in developing countries, a very useful purpose will have been served. 


\section{Acknowledgements}

The author and publishers wish to thank the following who have kindly given permission for the use of copyright material:

The Advertising Association for an adapted table on advertising, 1985;

Financial Times of London for material from various supplements;

International Monetary Fund for adapted material from International Financial Statistics, 1982;

Penguin Books Ltd for material from Development in a Divided World edited by Dudley Seers and Leonard Joy, 1971. Copyright (C) Penguin Books Ltd, 1970;

Prentice-Hall, Inc., for adapted material from Marketing Management by Philip Kotler, 4th edn., (C) 1980;

Starch Inra Hooper, Inc., for material from World Advertising Expenditures, 1979;

The Trilateral Commission for material from Trade in Manufactured Products with Developing Controls: Reinforcing the North-South Partnership by A. Fishlow, 1981;

Unwin Hyman Ltd for material from International Marketing by S. Majaro, 1977;

The World Bank for material from World Development Reports, 1986 and 1982, Oxford University Press, Inc.

Every effort has been made to trace all the copyright-holders, but if any have been inadvertently overlooked the publishers will be pleased to make the necessary arrangement at the first opportunity. 